\title{
SILVEIRA, Emerson J. S. da; SOFIATI, Flávio M. (Orgs.). Novas leituras do Campo Religioso Brasileiro. São Paulo: Ideias \& Letras, 2014.
}

Eurides Rodrigues *

O presente livro é uma coletânea organizada por dois autores já conhecidos por suas pesquisas e publicações na área das ciências sociais e religião. O primeiro é o Prof. Dr. Emerson José Sena da Silveira. Emerson é professor adjunto do Departamento de Ciência da Religião da Universidade Federal de Juiz de Fora (UFJF). Atualmente vem se dedicando a duas linhas de pesquisa. Na primeira dirige seu olhar para os católicos/evangélicos e suas memórias, tradições e estilos (espaço público, gênero, redes sociais). Na segunda, sua atenção se volta para as terapias complementares/integrativas e as cosmovisões e rituais religiosos (católicos, afro-brasileiros e outros). O segundo é o Prof. Dr. Flávio Munhoz Sofiati. Sofiati é professor adjunto de sociologia da Universidade Federal de Goiás (UFG), na Faculdade de Ciências Sociais. Sua experiência como professor e pesquisador está associada à área da Sociologia, com ênfase em teoria sociológica clássica, dos temas juventude e religião, catolicismo contemporâneo, movimento carismático e teologia da libertação.

Os textos colecionados, em sua grande maioria produzidos por jovens pesquisadores da religião, tratam de temas contemporâneos e de fronteira. Alguns 
se destacam pela maior importância a eles atribuídos pelos autores. Este é o caso, por exemplo, do turismo religioso, da espiritualidade virtual, do consumo do sagrado e da exportação de experiências religiosas brasileiras. Outros, pela forma que foram buscados e pinçados no campo e pelo tratamento dispensado. São exemplos os já conhecidos temas do pentecostalismo e do carismatismo. O tratamento dispensado na abordagem, tanto dos temas quanto dos dados e sujeitos observados, não perde de vista nem os clássicos e nem os contemporâneos pesquisadores e pensadores da religião. Na introdução que faz à obra, Jorge Claudio Ribeiro alega perceber em vários textos uma tendência que se constitui em um traço novidadeiro e necessário, mas ao mesmo tempo arriscado, qual seja: um "guiar-se pela intuição do potencial de descoberta presente na abordagem compreensiva e na intersubjetividade”.

São dez capítulos no total. Os organizadores distribuíram os capítulos em duas partes, sendo cinco capítulos para cada uma delas. A primeira parte recebeu o título de Fluxos, comunidades e semânticas do catolicismo. Os capítulos reunidos em torno deste título colocam em evidência as transformações, reações, combinações e novas tendências presentes no catolicismo brasileiro.

O capítulo de abertura é de Brenda Carranza (PUC Campinas) e Cecília Mariz (UERJ). Com a atenção voltada para a experiência da comunidade Canção Nova, as autoras buscam identificar os mecanismos que possibilitam a sua expansão, particularmente entre os jovens e para fora do Brasil. Para tanto, partem da compreensão que essa comunidade tem de seu carisma missionário e vocação evangelizadora por meio das novas tecnologias de comunicação.

O capítulo segundo, de autoria de Flávio Sofiati (UFG), traz uma síntese de suas pesquisas sobre religião e juventude, no intuito de contribuir para a construção de uma sociologia da juventude católica brasileira. Duas juventudes e dois contextos. A primeira é a juventude articulada pelo movimento carismático inserida no processo de pentecostalização do catolicismo brasileiro. A outra, 
articulada pela Teologia da Libertação, está representada nas Pastorais da Juventude.

O terceiro capítulo é de Emersom Sena (UFJF). Sua investigação e reflexão se voltam para o horizonte aberto pelas novas práticas religiosas, em particular para as devoções virtuais e ecorreligiosas, bem como para o turismo religioso chamando a atenção para o caráter ambíguo provocado por essas práticas no campo da religiosidade brasileira.

No quarto capítulo, a autora Eliane Martins de Oliveira retoma a discussão sobre o movimento carismático e a comunidade Canção Nova iniciada no capítulo primeiro. Sua contribuição, fruto de longa pesquisa realizada junto à comunidade, está associada ao que ela chamou de "perspectiva 'imaterial' da 'Canção Nova”, a qual se constitui no entorno de uma “'cosmologia' da 'Canção Nova”’(p. 123).

Concluindo a primeira parte, André Ricardo de Souza (UFSCar), traz um balanço histórico da presença da Renovação Carismática em território brasileiro. Entre os aspectos discutidos por Souza estão o crescimento, as feições adquiridas e os desdobramentos eclesiais e políticos "da face católica brasileira mais visível atualmente” (p. 164): a Renovação Carismática Católica.

$\mathrm{Na}$ segunda parte do livro, chamada Campo religioso, minorias $e$ evangelicismos, a reflexão se volta para a ascensão dos evangélicos e outras minorias religiosas que a seu modo também contribuem para a nova configuração do campo religioso brasileiro. O capítulo de abertura, escrito por Emerson Giumbelli (UFRGS), coloca em discussão dois aspectos fundamentais à compreensão da noção de campo religioso. O primeiro é a própria noção de “campo”, que será objeto de reflexão. Em seguida o foco da atenção se dirige para a noção de configuração do campo religioso. As reflexões propostas por Giumbelli, buscam compreender a pluralidade de manifestações do religioso. 
O capítulo seguinte, escrito por Péricles Andrade (UFS), procura identificar e compreender o novo estilo sacerdotal presente no campo religioso brasileiro: os artistas da fé. De acordo com Péricles, a investigação sobre o advento dos assim chamados padres midiáticos, ou padres cantores midiáticos, integrantes do movimento carismático católico traz consigo novos desafios à compreensão do campo religioso brasileiro.

No terceiro capítulo, o olhar de Cristina Maria de Castro (UFMG) sobre o campo religioso brasileiro se deteve na presença minoritária muçulmana em território nacional. Dentre as contribuições, uma para destaque: os resultados compartilhados de sua análise sobre a construção de identidades muçulmanas no campo religioso brasileiro.

O quarto capítulo, escrito por Paulo Gracino Junior (IUPERJ), coloca em discussão as principais interseções entre a expansão do pentecostalismo protestante e as culturas locais, alvo de sua ação evangelizadora. De acordo com Paulo Gracino, o trânsito religioso dos indivíduos entre as denominações religiosas se dá não por uma escolha racional, mas é determinado por processos históricos e estruturais.

O último capítulo traz uma reflexão do experiente pesquisador do pentecostalismo, Prof. Saulo Baptista (UEPA). A entrada dos pentecostais e dos neopentecostais na política e as consequentes disputas eleitorais e pelo exercício do poder nos parlamentos é o objeto da reflexão proposta por ele. Dentre os aspectos observados destaca-se a contribuição desses atores religiosos para o processo de construção da democracia, bem como para a preservação de certos vícios presentes na cultura política brasileira.

Em seu conjunto, os textos reunidos testemunham a pluralidade e a complexidade do campo religioso brasileiro. Um dos méritos da coletânea é reunir a produção de jovens e de experientes pesquisadores. Outro dado não menos importante está na atenção dispensada às novas formas de organização e de 
experiências religiosas. Um destaque especial é dado aos novos espaços e formas de cultivo da espiritualidade: o ciberespaço, o turismo religioso e ecorreligioso. A fidelidade aos clássicos e a escuta atenta dos contemporâneos é outro traço marcante dos textos. Enfim, se não se pode dizer que a leitura dos textos colecionados na presente obra é obrigatória aos pesquisadores do campo religioso brasileiro, ela o é, no entanto, indispensável. 